\title{
GMR
}

\section{In vitro effects and mechanisms of lycopene in MCF-7 human breast cancer cells}

\author{
S.J. Peng, J. Li, Y. Zhou, M. Tuo, X.X. Qin, Q. Yu, H. Cheng and Y.M. Li \\ Department of Breast Surgery, \\ The Central Hospital of EnShi Tujia and Miao Autonomous Prefecture, \\ Enshi, Hubei, China
}

Corresponding authors: S.J. Peng / J. Li

E-mail: pengshijung@sina.com / lijingjop@sina.com

Genet. Mol. Res. 16 (2): gmr16029434

Received October 14, 2016

Accepted February 23, 2017

Published April 13, 2017

DOI http://dx.doi.org/10.4238/gmr16029434

Copyright (C) 2017 The Authors. This is an open-access article distributed under the terms of the Creative Commons Attribution ShareAlike (CC BY-SA) 4.0 License.

\begin{abstract}
Breast cancer adversely affects the health status of women; therefore, the prevention and treatment of breast cancer is of critical importance. Lycopene is known to possess several biological effects such as removal of free radicals, alleviation of biological oxidative injury, and inhibition of tumor growth. In this study, we aimed to illustrate the effect of lycopene on tumor cell proliferation and modulation of cancer progression as well as its possible underlying mechanisms in human breast carcinoma cell line MCF-7 in vitro. MCF7 cells were treated with different lycopene concentrations for 24, 48, and $72 \mathrm{~h}$. Light field microscopy was used to observe cell morphology. MTT assay was used to determine the effect of lycopene on MCF-7 proliferation. Flow cytometry was employed to evaluate cell apoptosis. Real-time quantitative polymerase chain reaction was performed to detect the expression of $\mathrm{p} 53$ and Bax. Under microscopic examination, the untreated MCF-7 cells appeared to have a diamond or polygonal shape. Lycopene treatment resulted in cell shrinkage and breakage, whose severity increased in a dose and duration dependent manner. In addition, reduced cell proliferation and increased apoptosis $(\mathrm{P}<0.05)$
\end{abstract}

Genetics and Molecular Research 16 (2): gmr16029434 
were observed using MTT assay and flow cytometry, respectively. Moreover, lycopene could also upregulate the expression of p53 and Bax mRNAs in MCF-7 cells. In conclusion, lycopene inhibits proliferation and facilitates apoptosis of MCF-7 cells in vitro, possibly by regulating the expression of $\mathrm{p} 53$ and Bax.

Key words: Lycopene; MCF-7 cells; p53; Bax; Breast cancer; In vitro study

\section{INTRODUCTION}

The incidence of breast cancer has increased globally, and it has become the most common malignant cancer in women. Breast cancer severely affects women health. The development of modern medicine has largely improved the early diagnosis rate of cancer, and it has resulted in drugs and treatment approaches that can lead to increased survival rate in patients. Based on the pathological types, stages, and the biological activities of patients, various treatment strategies such as surgery, radiation, endocrine therapy, chemotherapy, molecular target therapy, Chinese medicine, and immunotherapy can be selected. However, all these methods have certain adverse effects and variable efficacy. Therefore, the establishment of anti-tumor drugs with specific gene locus, wide spectrum, high efficacy, and low toxicity is of critical importance for the treatment of breast cancer.

Lycopene is a carotenoid pigment found in red vegetables and fruits, especially in tomatoes. It did not draw much attention previously because it lacks vitamin A activity. However, recent studies have revealed the potential roles of lycopene, such as removal of free radicals, alleviation of bio-oxidative stress, modulation of body immune functions, and prevention of cardiovascular disease (Trejo-Solís et al., 2013; Cefali et al., 2015; Ilahy et al., 2016). In addition, lycopene can exert anti-tumor effects via regulation of cell growth factor signaling pathways, initiation of cell cycle arrest, and induction of cell apoptosis (Ono et al., 2015). Being a natural component in daily diet, lycopene has several advantages such as fewer adverse effects and easy extraction method, which attract extensive research interests in its anti-tumor effects. Previous findings showed that the intake of pro-lycopene was closely correlated with the incidence of prostate cancer (Wang et al., 2015a,b). Lycopene concentration in patients with pulmonary cancer was significantly lower than that in healthy individuals (Asbaghi et al., 2015). However, the role of lycopene in breast cancer is still controversial. One study showed that carotenoid intake was negatively correlated with estrogen receptor [ER (-)] breast cancer, but not with ER (+) cases (Zhang et al., 2012). Another study suggested that the intake of peripheral carotenoids, including lycopene and $\beta$-carotid, could decrease the risk of breast cancer, especially for the ER (-) subtypes (Eliassen et al., 2012).

The tumor suppressor gene $\mathrm{p} 53$ plays an important role in the regulation of cell cycle, as it arrests cell growth from $\mathrm{G}$ phase into $\mathrm{S}$ phase, thereby inducing cell apoptosis (Sohn et al., 2003). Overexpression of the pro-apoptotic gene Bax can induce cell apoptosis (Rampino et al., 1997). Bax is also a downstream effector of early p53 response gene (Brady and GilGómez, 1998). A previous study showed cell cycle arrest by lycopene (Takeshima et al., 2014). Given the contradicting results obtained from previous studies, the exact role of lycopene in MCF-7 cells, which is an ER (+) breast cancer cell line, remains poorly understood. In this study, we aimed to investigate the effect of lycopene in MCF-7 cells by treating them with

Genetics and Molecular Research 16 (2): gmr16029434 
different concentrations of lycopene. The mRNA levels of p53 and Bax gene were determined to explore the possible effects and related mechanisms of lycopene in MCF-7 cells.

\section{MATERIAL AND METHODS}

\section{Reagents}

Human breast carcinoma cell line MCF-7 was purchased from ATCC cell bank (USA). The reagents used in this study are: RPMI 1640 culture medium (Gibco, Carlsbad, CA, USA); fetal bovine serum (FBS; Hyclone, Logan, UT, USA); streptomycin-penicillin dual antibiotic solution (Gibco); Dimethyl sulfoxide (DMSO), 3-(4,5-Dimethylthiazol-2-yl)-2,5-Diphenyltetrazolium Bromide (MTT), and apoptotic test kits (Beyotime Biotechnology, Shanghai, China); Trizol RNA extraction kit (Invitrogen, Carlsbad, US); real-time fluorescent polymerase chain reaction (qPCR) test kit (TaKaRa Biomedicals, Kusatsu, Shiga, Japan); gel imaging system and fluorescent PCR cycler model ViiA7 (ABI, Thermo Fisher Scientific, Waltham, MA,USA).

\section{Cell culture}

Human breast cancer MCF-7 cells were cultured in RPMI 1640 medium containing $10 \% \mathrm{FBS}, 100 \mathrm{U} / \mathrm{mL}$ streptomycin, and $100 \mathrm{U} / \mathrm{mL}$ penicillin in a humidified chamber with $5 \% \mathrm{CO}_{2}$ at $37^{\circ} \mathrm{C}$. The cells were passaged every 2-3 days. During passaging, the culture medium was discarded, followed by rinsing twice with PBS. Then, the cells were digested by treatment with $0.25 \%$ trypsin for $30 \mathrm{~s}$ to harvest adherent cells for the preparation of single-cell suspensions, which were centrifuged at $1000 \mathrm{~g}$ for $5 \mathrm{~min}$. The supernatants were discarded, and the cells were re-suspended for cell culture.

\section{MTT assay}

The cells at $\log$ phase were inoculated on 96-well plates, with $5 \times 10^{3}$ cells in each well. A complete medium of RPMI 1640 was added to incubate cells for $24 \mathrm{~h}$, at $37^{\circ} \mathrm{C}$ under $5 \% \mathrm{CO}_{2}$. The cells were treated with different concentrations of lycopene $(0,2,4,8$, and 16 $\mu \mathrm{M})$ for different durations $(24,48$, and $72 \mathrm{~h})$ and with the blank control, which contained only $200 \mu \mathrm{L}$ culture medium, in parallel. Lycopene treatment was performed in five parallel wells for each concentration. After treatment, $20 \mu \mathrm{L}$ MTT working solution $(5.0 \mathrm{~g} / \mathrm{L})$ was added to each well and incubated for $4 \mathrm{~h}$. The supernatants were then discarded. MTT-formazon crystals were dissolved by the addition of $150 \mu \mathrm{L}$ DMSO for $10 \mathrm{~min}$ until complete dissolution of the purple crystals. The absorbance (A) value in each well at $490 \mathrm{~nm}$ was measured.

$$
\text { Cell survival rate }=\left(\mathrm{A}_{\text {Experimental group }}-\mathrm{A}_{\text {Blank }}\right) /\left(\mathrm{A}_{\text {Control }}-\mathrm{A}_{\text {Blank }}\right)
$$

\section{Flow cytometry}

The cell suspensions were added on a 6-well plate, which was acclimated for $24 \mathrm{~h}$. Then, different concentrations of lycopene $(0,2,4,8$, and $16 \mu \mathrm{M})$ were added, followed by subsequent incubation for different durations $(24,48$, and $72 \mathrm{~h}$ ) in triplicates. After lycopene treatment, cell morphology was observed using light field microscopy. Trypsin was used to digest the cells. The cells were then rinsed twice with PBS and centrifuged at $1000 \mathrm{~g}$ for $5 \mathrm{~min}$. The cells $\left(1 \times 10^{6}\right)$ were

Genetics and Molecular Research 16 (2): gmr16029434 
re-suspended in PBS and centrifuged at $1000 \mathrm{~g}$ for $5 \mathrm{~min}$. The supernatants were discarded, and the cells were re-suspended in $195 \mu \mathrm{L}$ binding buffer, followed by the addition of $5 \mu \mathrm{L}$ Annexin V-FITC. Then, the cells were incubated in propidium iodide $(10 \mu \mathrm{L}, \mathrm{PI})$ solution for $20 \mathrm{~min}$ at $25^{\circ} \mathrm{C}$ in the dark. The apoptosis rate was measured using flow cytometry.

\section{mRNA assay}

Total RNA was extracted with Trizol reagent. The purity and concentration of RNA were determined by Nano Drop (Thermo Fisher Scientific, Waltham, MA,USA). RNA integrity was evaluated by $1 \%$ agarose gel electrophoresis. cDNA was synthesized from RNA $(1 \mu \mathrm{g})$ using a reverse transcription kit (TaKaRa). Quantitative PCR was performed by using real-time fluorescent test kit. The reaction mixture comprised $5 \mu \mathrm{L} 2 \mathrm{X}$ SYBR Green Mixture, $0.5 \mu \mathrm{L}$ cDNA, $0.5 \mu \mathrm{L}$

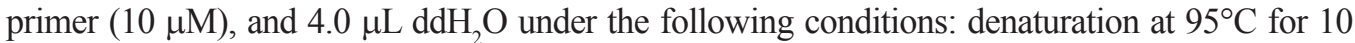
min, followed by 40 cycles of $95^{\circ} \mathrm{C}$ for $15 \mathrm{~s}$ and annealing at $60^{\circ} \mathrm{C}$ for $60 \mathrm{~s}$ on a model ViiA7 fluorescent quantitative PCR cycler in triplicates, using $\beta$-actin as the internal reference.

\section{Statistical analysis}

SPSS19.0 software was used to perform statistical analysis. Data following a normal distribution are reported as means \pm standard deviation (SD). Analysis of variance (ANOVA) was used for analysis of data. Fisher's Least Significant Difference (LSD) test was used to compare two groups. $\mathrm{P}<0.05$ was considered statistically significant.

\section{RESULTS}

\section{Effects of lycopene on MCF-7 cell morphology}

After lycopene treatment at different concentrations, the morphology of MCF-7 cells was observed under an inverted microscope. Untreated MCF-7 cells appeared to have a diamond or polygonal shape with normal proliferation (Figure 1). The number of MCF-7 cells decreased after lycopene treatment, and they showed shrinkage and breakage. These phenomena were aggravated with increasing concentrations and treatment durations.

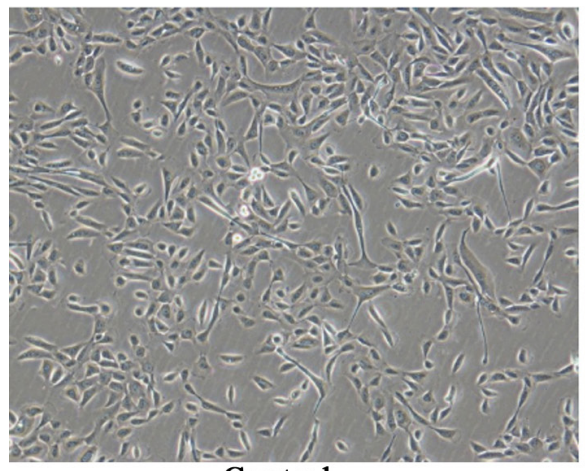

Control

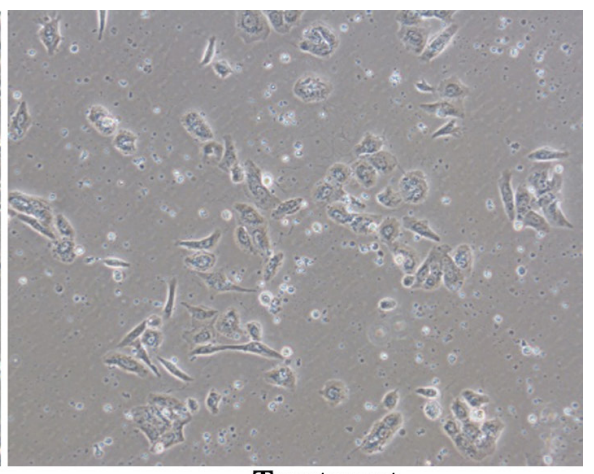

Treatment

Figure 1. Effects of lycopene on MCF-7 cell morphology. 


\section{Effects of lycopene on MCF-7 cell proliferation}

MTT assay was used to test the viability of MCF-7 cells treated with different lycopene concentrations for 24, 48, and $72 \mathrm{~h}$. Lycopene significantly inhibited MCF-7 cell proliferation in a dose- and time-dependent manner. Significant inhibitory effects were observed with increasing concentrations or longer treatment periods (Table 1). In particular, the most potent inhibitory effects on cell proliferation were observed in cells treated with 16 $\mu \mathrm{M}$ lycopene for $72 \mathrm{~h}$.

\section{Table 1. Effects of lycopene on MCF-7 cell proliferation.}

\begin{tabular}{l|c|c|c}
\hline Concentration & $24 \mathrm{~h}$ & $48 \mathrm{~h}$ & $72 \mathrm{~h}$ \\
\hline $0 \mu \mathrm{M}$ & $1.00 \pm 0.040$ & $1.00 \pm 0.038$ & $1.00 \pm 0.039$ \\
\hline $2 \mu \mathrm{M}$ & $0.95 \pm 0.034^{*}$ & $0.92 \pm 0.039^{*}$ & $0.89 \pm 0.042^{*}$ \\
\hline $4 \mu \mathrm{M}$ & $0.90 \pm 0.035^{*}$ & $0.83 \pm 0.041^{*}$ & $0.78 \pm 0.040^{*}$ \\
\hline $8 \mu \mathrm{M}$ & $0.82 \pm 0.036^{*}$ & $0.75 \pm 0.040^{*}$ & $0.62 \pm 0.039^{*}$ \\
\hline $16 \mu \mathrm{M}$ & $0.78 \pm 0.040^{*}$ & $0.68 \pm 0.036^{*}$ & $0.57 \pm 0.038^{*}$ \\
\hline
\end{tabular}

$* \mathrm{P}<0.05$ compared to control $(0 \mu \mathrm{M})$ group.

\section{Effects of lycopene on MCF-7 cell apoptosis}

After treatment of MCF-7 cells with different lycopene concentrations, apoptosis was detected using flow cytometry. Significant difference in cell apoptosis rate was observed between the control and lycopene-treated groups (Figure 2 and Table 2, $\mathrm{P}<0.05$ ). Cell apoptosis gradually increased with increasing lycopene concentrations, suggesting a dose-dependent relationship. In addition, longer treatment durations increased the cell apoptotic rate.
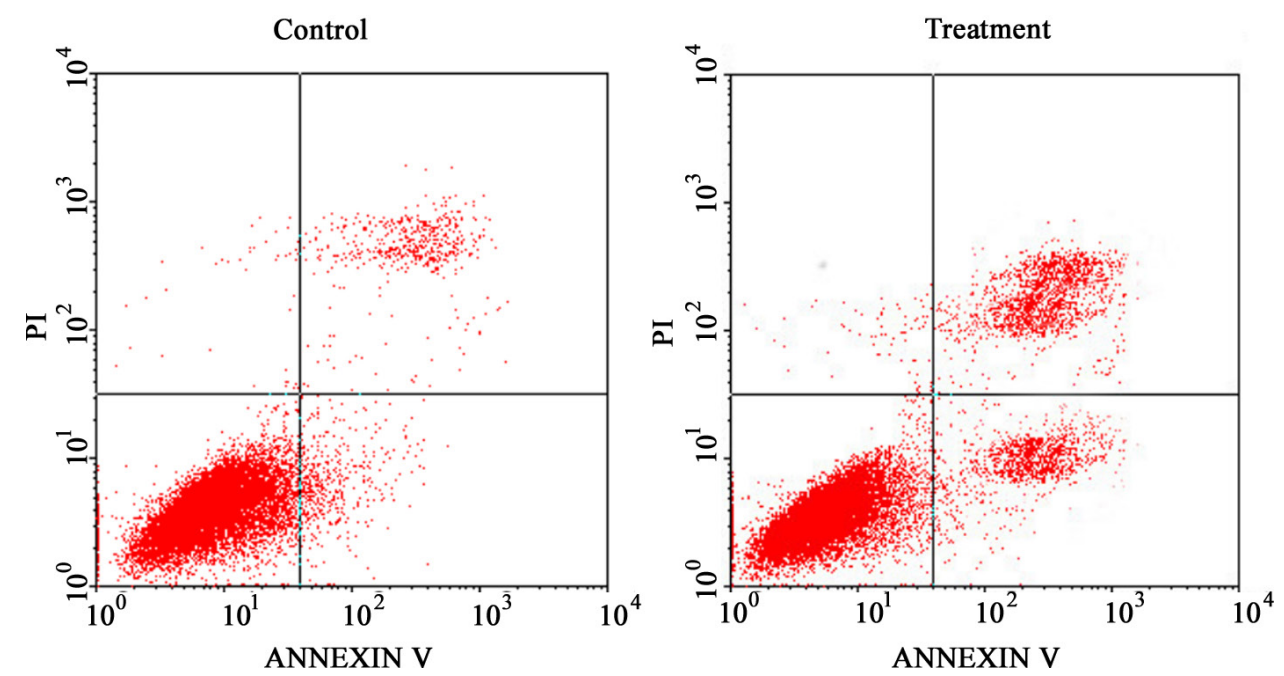

Figure 2. Flow cytometry for cell apoptosis.

Genetics and Molecular Research 16 (2): gmr16029434 
Table 2. Effects of lycopene on cell apoptosis.

\begin{tabular}{l|c|c|c}
\hline Concentration & $24 \mathrm{~h}(\%)$ & $48 \mathrm{~h}(\%)$ & $72 \mathrm{~h}(\%)$ \\
\hline $0 \mu \mathrm{M}$ & $3.12 \pm 1.01$ & $3.26 \pm 1.45$ & $3.45 \pm 1.25$ \\
\hline $2 \mu \mathrm{M}$ & $5.26 \pm 1.21^{*}$ & $6.75 \pm 1.34^{*}$ & $6.98 \pm 1.26^{*}$ \\
\hline $4 \mu \mathrm{M}$ & $7.35 \pm 1.13^{*}$ & $9.12 \pm 1.47^{*}$ & $11.54 \pm 1.89^{*}$ \\
\hline $8 \mu \mathrm{M}$ & $10.12 \pm 2.13^{*}$ & $14.25 \pm 1.78^{*}$ & $18.95 \pm 2.13^{*}$ \\
\hline $16 \mu \mathrm{M}$ & $13.14 \pm 1.56^{*}$ & $20.56 \pm 2.15^{*}$ & $28.69 \pm 2.56^{*}$ \\
\hline
\end{tabular}

$* \mathrm{P}<0.05$ compared to control $(0 \mu \mathrm{M})$ group.

\section{Effects of lycopene on Bax and p53 mRNA expression levels}

The mRNA levels of Bax and p53 in lycopene-treated cells were semi-quantitatively measured using $\beta$-actin as the internal reference gene. The mRNA levels of Bax and p53 gradually increased with increasing doses of lycopene and duration of treatment (Tables 3 and 4).

Table 3. Expression of bax mRNA by lycopene.

\begin{tabular}{l|c|c|c}
\hline Concentration & $24 \mathrm{~h}$ & $48 \mathrm{~h}$ & $72 \mathrm{~h}$ \\
\hline $0 \mu \mathrm{M}$ & $1.00 \pm 0.11$ & $1.00 \pm 0.10$ & $1.00 \pm 0.12$ \\
\hline $2 \mu \mathrm{M}$ & $1.13 \pm 0.12$ & $1.24 \pm 0.11^{*}$ & $1.29 \pm 0.10^{*}$ \\
\hline $4 \mu \mathrm{M}$ & $1.24 \pm 0.12^{*}$ & $1.28 \pm 0.13^{*}$ & $1.45 \pm 0.12^{*}$ \\
\hline $8 \mu \mathrm{M}$ & $1.32 \pm 0.09^{*}$ & $1.42 \pm 0.12^{*}$ & $1.68 \pm 0.13^{*}$ \\
\hline $16 \mu \mathrm{M}$ & $1.46 \pm 0.10^{*}$ & $1.60 \pm 0.09^{*}$ & $2.08 \pm 0.14^{*}$ \\
\hline
\end{tabular}

$* \mathrm{P}<0.05$ compared to control $(0 \mu \mathrm{M})$ group.

Table 4. Expression of p53 mRNA by lycopene.

\begin{tabular}{l|c|c|c}
\hline Concentration & $24 \mathrm{~h}$ & $48 \mathrm{~h}$ & $72 \mathrm{~h}$ \\
\hline $0 \mu \mathrm{M}$ & $1.00 \pm 0.09$ & $1.00 \pm 0.08$ & $1.00 \pm 0.10$ \\
\hline $2 \mu \mathrm{M}$ & $1.11 \pm 0.13$ & $1.25 \pm 0.12^{*}$ & $1.31 \pm 0.08^{*}$ \\
\hline $4 \mu \mathrm{M}$ & $1.26 \pm 0.12^{*}$ & $1.37 \pm 0.13^{*}$ & $1.48 \pm 0.13^{*}$ \\
\hline $8 \mu \mathrm{M}$ & $1.43 \pm 0.13^{*}$ & $1.58 \pm 0.14^{*}$ & $1.77 \pm 0.12^{*}$ \\
\hline $16 \mu \mathrm{M}$ & $1.50 \pm 0.10^{*}$ & $1.75 \pm 0.11^{*}$ & $1.92 \pm 0.14^{*}$ \\
\hline
\end{tabular}

$* \mathrm{P}<0.05$ compared to control $(0 \mu \mathrm{M})$ group.

\section{DISCUSSION}

Natural plant extracts have several advantages over chemotherapeutic drugs including fewer adverse effects. In addition, they are suitable for human use. As the antitumor components of plant extracts can be obtained through natural diet, their daily dietary intake can help in preventing cancer. Both in vitro studies and epidemiology surveys suggested the anti-tumor potency of lycopene (Elgass et al., 2014; Fu et al., 2014; Bhatia et al., 2015; Eliassen et al., 2015; Yan et al., 2016). However, there was inconsistency regarding the exact role of lycopene in breast carcinoma. Therefore, in this study, we aimed to investigate the effect of lycopene in an in vitro breast cancer model.

Lycopene treatment resulted in MCF-7 cell shrinkage and damage, which became worse at higher concentrations or longer treatment times or both. MTT assay showed that the activity of MCF-7 cells gradually decreased with increasing lycopene concentrations

Genetics and Molecular Research 16 (2): gmr16029434 
and treatment duration. The most significant inhibitory effects were observed in cells treated with $16 \mu \mathrm{M}$ lycopene for $72 \mathrm{~h}$. Thus, lycopene showed an inhibitory effect on MCF-7 cell proliferation. Flow cytometry assay showed that lycopene induced the apoptosis of MCF-7 cells in a dose- and time-dependent manner, indicating that lycopene inhibited cell proliferation by inducing MCF-7 cell apoptosis. The results of our study were consistent with those of previous studies, which showed that lycopene can arrest cells at G0/G1 phase to inhibit MCF7 cell proliferation (Takeshima et al., 2014) and induce apoptosis (Teodoro et al., 2012), and provided further evidences on the anti-tumor effects of lycopene on ER $(+)$ breast cancer.

We also explored the possible mechanisms underlying the effect of lycopene on MCF7 cells. Our results showed that the mRNA levels of both p53 and Bax increased significantly in a dose- and time-dependent manner after lycopene treatment, suggesting the involvement of p53 and Bax in lycopene-induced MCF-7 cell apoptosis. Previous findings suggested that lycopene could induce the overexpression of Bax in MCF-7 cells (Takeshima et al., 2014). Another study showed decreased expression of Bcl-2 gene, which is closely correlated with Bax function, in MCF-7 cells after lycopene treatment (Li et al., 2002). When overexpressed, the Bcl-2 gene binds to Bax and induces the inhibition of cell apoptosis (Oltvai et al., 1993). These findings supported our conclusion. In addition, increased p53 expression was observed in prostate cancer cells after lycopene treatment (Palozza et al., 2010)

In summary, we demonstrated that lycopene induced apoptosis and inhibited MCF7 cell proliferation, possibly by regulating the expression of p53 and Bax. However, owing to the inherent complicated mechanisms of breast cancer, future investigations using breast cancer in vivo model or other breast cancer cell lines are required to confirm these findings.

\section{Conflicts of interest}

The authors declare no conflict of interest.

\section{ACKNOWLEDGMENTS}

We would like to thank the anonymous reviewers for reviewing this manuscript.

\section{REFERENCES}

Asbaghi S, Saedisomeolia A, Hosseini M, Honarvar NM, et al. (2015). Dietary Intake and Serum Level of Carotenoids in Lung Cancer Patients: A Case-Control Study. Nutr. Cancer 67: 893-898. http://dx.doi.org/10.1080/01635581.20 $\underline{15.1055365}$

Bhatia N, Gupta P, Singh B and Koul A (2015). Lycopene Enriched Tomato Extract Inhibits Hypoxia, Angiogenesis, and Metastatic Markers in early Stage N-Nitrosodiethylamine Induced Hepatocellular Carcinoma. Nutr. Cancer 67: 1268-1275. http://dx.doi.org/10.1080/01635581.2015.1087040

Brady HJ and Gil-Gómez G (1998). Bax. The pro-apoptotic Bcl-2 family member, Bax. Int. J. Biochem. Cell Biol. 30: 647-650. http://dx.doi.org/10.1016/S1357-2725(98)00006-5

Cefali LC, Cazedey EC, Souza-Moreira TM, Correa MA, et al. (2015). Antioxidant Activity and Validation of Quantification Method for Lycopene Extracted from Tomato. J. AOAC Int. 98: 1340-1345. http://dx.doi.org/10.5740/jaoacint.14-151

Elgass S, Cooper A and Chopra M (2014). Lycopene treatment of prostate cancer cell lines inhibits adhesion and migration properties of the cells. Int. J. Med. Sci. 11: 948-954. http://dx.doi.org/10.7150/ijms.9137

Eliassen AH, Hendrickson SJ, Brinton LA, Buring JE, et al. (2012). Circulating carotenoids and risk of breast cancer: pooled analysis of eight prospective studies. J. Natl. Cancer Inst. 104: 1905-1916. http://dx.doi.org/10.1093/jnci/djs461

Eliassen AH, Liao X, Rosner B, Tamimi RM, et al. (2015). Plasma carotenoids and risk of breast cancer over 20 y of follow-up. Am. J. Clin. Nutr. 101: 1197-1205. http://dx.doi.org/10.3945/ajen.114.105080

Genetics and Molecular Research 16 (2): gmr16029434 
Fu LJ, Ding YB, Wu LX, Wen CJ, et al. (2014). The Effects of Lycopene on the Methylation of the GSTP1 Promoter and Global Methylation in Prostatic Cancer Cell Lines PC3 and LNCaP. Int. J. Endocrinol. 2014: 620165. http://dx.doi. org $/ 10.1155 / 2014 / 620165$

Ilahy R, Piro G, Tlili I, Riahi A, et al. (2016). Fractionate analysis of the phytochemical composition and antioxidant activities in advanced breeding lines of high-lycopene tomatoes. Food Funct. 7: 574-583. http://dx.doi.org/10.1039/ C5FO00553A

Li Z, Wang Y and Mo B (2002). [The effects of carotenoids on the proliferation of human breast cancer cell and gene expression of bcl-2]. Zhonghua Yu Fang Yi Xue Za Zhi 36: 254-257.

Oltvai ZN, Milliman CL and Korsmeyer SJ (1993). Bcl-2 heterodimerizes in vivo with a conserved homolog, Bax, that accelerates programmed cell death. Cell 74: 609-619. http://dx.doi.org/10.1016/0092-8674(93)90509-O

Ono M, Takeshima M and Nakano S (2015). Mechanism of the Anticancer Effect of Lycopene (Tetraterpenoids). Enzymes 37: 139-166. http://dx.doi.org/10.1016/bs.enz.2015.06.002

Palozza P, Colangelo M, Simone R, Catalano A, et al. (2010). Lycopene induces cell growth inhibition by altering mevalonate pathway and Ras signaling in cancer cell lines. Carcinogenesis 31: 1813-1821. http://dx.doi.org/10.1093/ $\underline{\operatorname{carcin} / \text { bgq } 157}$

Rampino N, Yamamoto H, Ionov Y, Li Y, et al. (1997). Somatic frameshift mutations in the BAX gene in colon cancers of the microsatellite mutator phenotype. Science 275: 967-969. http://dx.doi.org/10.1126/science.275.5302.967

Sohn SK, Jung JT, Kim DH, Kim JG, et al. (2003). Prognostic significance of bcl-2, bax, and p53 expression in diffuse large B-cell lymphoma. Am. J. Hematol. 73: 101-107. http://dx.doi.org/10.1002/ajh.10333

Takeshima M, Ono M, Higuchi T, Chen C, et al. (2014). Anti-proliferative and apoptosis-inducing activity of lycopene against three subtypes of human breast cancer cell lines. Cancer Sci. 105: 252-257. http://dx.doi.org/10.1111/ cas. 12349

Teodoro AJ, Oliveira FL, Martins NB, Maia GdeA, et al. (2012). Effect of lycopene on cell viability and cell cycle progression in human cancer cell lines. Cancer Cell Int. 12: 36. http://dx.doi.org/10.1186/1475-2867-12-36

Trejo-Solís C, Pedraza-Chaverrí J, Torres-Ramos M, Jiménez-Farfán D, et al. (2013). Multiple molecular and cellular mechanisms of action of lycopene in cancer inhibition. Evid. Based Complement. Alternat. Med. 2013: 705121. http://dx.doi.org/10.1155/2013/705121

Wang Y, Cui R, Xiao Y, Fang J, et al. (2015a). Correction: Effect of Carotene and Lycopene on the Risk of Prostate Cancer: A Systematic Review and Dose-Response Meta-Analysis of Observational Studies. PLoS One 10: e0140415. http:// dx.doi.org/10.1371/journal.pone. 0140415

Wang Y, Cui R, Xiao Y, Fang J, et al. (2015b). Effect of Carotene and Lycopene on the Risk of Prostate Cancer: A Systematic Review and Dose-Response Meta-Analysis of Observational Studies. PLoS One 10: e0137427. http:// dx.doi.org/10.1371/journal.pone. 0137427

Yan B, Lu MS, Wang L, Mo XF, et al. (2016). Specific serum carotenoids are inversely associated with breast cancer risk among Chinese women: a case-control study. Br. J. Nutr. 115: 129-137.http://dx.doi.org/10.1017/S000711451500416X

Zhang X, Spiegelman D, Baglietto L, Bernstein L, et al. (2012). Carotenoid intakes and risk of breast cancer defined by estrogen receptor and progesterone receptor status: a pooled analysis of 18 prospective cohort studies. Am. J. Clin. Nutr. 95: 713-725. http://dx.doi.org/10.3945/ajen.111.014415

Genetics and Molecular Research 16 (2): gmr16029434 